\title{
Oxidant-Induced Increases in Mucosal Permeability in Developing Piglets
}

\author{
E. SUSAN CLARK, KAREN D. CRISSINGER, AND D. NEIL GRANGER \\ with the technical assistance of Donna $L$. Butney \\ Departments of Physiology/Biophysics [E.S.C., K.D.C., D.N.G.] and Pediatrics [K.D.C., D.L.B.], Louisiana State \\ University Medical Center. Shreveport. Louisiana $71130-3932$
}

\begin{abstract}
Reactive oxygen metabolites have been implicated in the pathogenesis of mucosal injury induced by ischemia-reperfusion in adult animals, with recent interest centering on the capacity of polymorphonuclear neutrophilderived oxidants to mediate this injury. A role for oxidants has also been postulated in the etiology of neonatal necrotizing enterocolitis. Based on evidence that the intrinsic capacity of the neonatal piglet intestine to detoxify hydrogen peroxide $\left(\mathrm{H}_{2} \mathrm{O}_{2}\right)$ is minimal relative to that of older piglets, we characterized the changes in mucosal permeability induced by luminal perfusion with $\mathrm{H}_{2} \mathrm{O}_{2}$ and hypochlorous acid at concentrations that can be produced physiologically by activated neutrophils $(0.05 \mathrm{mmol} / \mathrm{L}, 0.1$ $\mathrm{mmol} / \mathrm{L}$, and $0.5 \mathrm{mmol} / \mathrm{L}$ ), in the distal ileum of 1-d-and 1-mo-old piglets. Mucosal permeability was quantitated by measurement of blood-to-lumen clearance of 51-labeled chromium EDTA. Luminal perfusion with either $\mathrm{H}_{2} \mathrm{O}_{2}$ $(0.05 \mathrm{mmol} / \mathrm{L}$ and $0.1 \mathrm{mmol} / \mathrm{L})$ or hypochlorous acid $(0.1$ $\mathrm{mmol} / \mathrm{L}$ and $0.5 \mathrm{mmol} / \mathrm{L}$ ) significantly increased mucosal permeability in newborn piglets but did not affect mucosal permeability in 1-mo-old animals. Perfusion with 0.5 $\mathrm{mmol} / \mathrm{L} \mathrm{H}_{2} \mathrm{O}_{2}$ significantly increased mucosal permeability over control values in both age groups, but injury in the newborn intestine was significantly greater than that observed in 1-mo-old animals. Thus, as predicted by the reduced intrinsic capacity of the mucosa of neonatal piglets to detoxify $\mathrm{H}_{2} \mathrm{O}_{2}$, the ileum of newborn piglets is more vulnerable to oxidant-induced mucosal injury than is the ileum of older animals. (Pediatr Res 28: 28-30, 1990)
\end{abstract}

\section{Abbreviations}

$\mathrm{H}_{2} \mathrm{O}_{2}$, hydrogen peroxide

HOCl, hypochlorous acid

${ }^{51}$ Cr-EDTA, 51-labeled chromium EDTA

SOD, superoxide dismutase

A considerable quantity of experimental data supports the hypothesis that reactive oxygen metabolites mediate the microvascular and mucosal permeability changes encountered after reperfusion of ischemic intestine in adult animals (1-7). The potential for reactive oxygen metabolites to induce injury is dependent upon several factors. First, a source of these toxic oxygen species must exist. The two major sources of oxygenderived free radicals in adult intestine are xanthine oxidase (8)

\section{Received December 27, 1989; accepted March 7, 1990.}

Correspondence: Karen D. Crissinger, M.D., Ph.D., Department of Pediatrics, Louișiana State University Medical Center. P.O. Box 33932, Shreveport, LA 7 I I303932 .

Supported by grant DK-33594 from the National Institutes of Health and a National Research Service Award (DK08056) from the NIH (K.D.C.). and the NADPH-oxidase associated with phagocytic leukocytes (neutrophils, eosinophils, and macrophages) (9). Xanthine oxidase and activated phagocytes can produce large quantities of cytotoxic oxidants including superoxide, $\mathrm{H}_{2} \mathrm{O}_{2}$, and possibly hydroxyl radicals (10). Another determinant of oxidant-mediated tissue injury is the antioxidant capacity of the tissue. Cellular enzymatic defense mechanisms include SOD, which dismutates the superoxide anion to $\mathrm{H}_{2} \mathrm{O}_{2}$ and oxygen; and catalase and glutathione peroxidase, which detoxify $\mathrm{H}_{2} \mathrm{O}_{2}$ (11-13). Finally, the ability of oxidants to induce tissue damage must be considered because free radicals differ in stability, tendency to attack specific substrates (lipids, proteins, DNA, RNA), and ability to diffuse from sites of generation and traverse biologic membranes $(14,15)$. For example, $\mathrm{H}_{2} \mathrm{O}_{2}$ can rapidly cross plasma membranes because of its small size and neutral charge (16), but it diffuses relatively large distances because of its slow reaction with organic substrates.

In neonatal intestine, a role for reactive oxygen metabolites has been postulated $(17-20)$ in the pathogenesis of necrotizing enterocolitis. Recently, it has been demonstrated that the intestinal mucosa of neonatal piglets contains no xanthine oxidase, but a significant number of resident phagocytic cells are present that have the capacity, when activated, to produce oxidants such as $\mathrm{H}_{2} \mathrm{O}_{2}$ and $\mathrm{HOCl}(21)$. It also appears that the neonatal piglet intestine is predisposed to $\mathrm{H}_{2} \mathrm{O}_{2}$-induced cell injury due to the absence of catalase activity, low glutathione peroxidase activity, and high basal SOD activity. Because the product of SODcatalyzed dismutation of superoxide is $\mathrm{H}_{2} \mathrm{O}_{2}$ and oxygen, one would expect higher fluxes of $\mathrm{H}_{2} \mathrm{O}_{2}$ within the neonatal piglet enterocyte than in that of older animals. Thus, the objective of our study was to determine whether the neonatal intestine is more susceptible to mucosal injury induced by physiologic levels of $\mathrm{H}_{2} \mathrm{O}_{2}$ and $\mathrm{HOCl}$, as predicted by the decreased mucosal antioxidant capacity of newborn ileum (22-24).

\section{MATERIALS AND METHODS}

Hampshire/Yorkshire piglets of either sex, ages 1-d-old $(n=$ $17,1.2 \pm 0.2 \mathrm{~kg})$ and 1 -mo-old $(n=10,7.4 \pm 2.1 \mathrm{~kg})$ were studied. One-d-old piglets were never nursed $(n=15)$ or were fasted for $16 \mathrm{~h}(n=2)$ before the experiment. One-mo-old animals were fasted for $24 \mathrm{~h}$.

Surgical procedure. After intramuscular injection with ketamine hydrochloride $(20 \mathrm{mg} / \mathrm{kg})$, and xylazine $(2 \mathrm{mg} / \mathrm{kg})$, the animals were anesthetized with i.v. pentobarbital sodium (15 $\mathrm{mg} / \mathrm{kg}$ ) and anesthesia was maintained throughout the experiment with additional doses of pentobarbital sodium $(5 \mathrm{mg} / \mathrm{kg})$ as needed.

The animals were artificially ventilated (Harvard Apparatus intermediate ventilator, South Natick, MA) via a tracheostomy at a tidal volume and respiratory rate to maintain normal arterial blood gases and $\mathrm{pH}$ (Instrumentation Laboratory Model 1304 $\mathrm{pH} /$ blood gas analyzer, Lexington, MA). Cannulas were inserted 
into the left carotid artery to monitor systemic blood pressure and into the right jugular vein for administration of pentobarbital and maintenance of hydration. Body temperature was maintained at $38^{\circ} \mathrm{C}$.

The abdomen was opened through a midline incision and the renal vessels were ligated to prevent urinary excretion of ${ }^{51} \mathrm{Cr}$ EDTA (New England Nuclear, Boston, MA). Loops of ileum, approximately $15 \mathrm{~cm}$ in length, were isolated, cannulated at both proximal and distal ends, and flushed with warm lactated Ringer solution. The intestine and abdominal contents were subsequently covered with plastic wrap to prevent evaporative water loss.

Experimental protocol. The cannulated ileal segment was perfused with warm lactated Ringer solution at a rate of $1 \mathrm{~mL} / \mathrm{min}$. ${ }^{51}$ Cr-EDTA was injected i.v., such that plasma cpm were at least $25000 / \mathrm{mL}$ ( $100-150 \mu \mathrm{Ci} / \mathrm{kg}$ ). Thirty min were allowed for tissue equilibration of the ${ }^{51} \mathrm{Cr}-\mathrm{EDTA}$, after which $0.5 \mathrm{~mL}$ of plasma and the luminal perfusate were collected during each $20-\mathrm{min}$ interval. Solutions of $\mathrm{H}_{2} \mathrm{O}_{2}$ and $\mathrm{HOCl}(0.05 \mathrm{mmol} / \mathrm{L}, 0.1 \mathrm{mmol} /$ $\mathrm{L}, 0.5 \mathrm{mmol} / \mathrm{L}$ ) were prepared in lactated Ringer solution immediately before each experiment. After 60 min of perfusion with lactated Ringer solution, ileal loops were perfused for an additional $180 \mathrm{~min}$ with either lactated Ringer solution $(n=2$ Ioops for 1 -d- and $n=3$ loops for 1-mo-olds), $\mathrm{H}_{2} \mathrm{O}_{2}$ ( $n=5$ loops for each concentration, except $n=2$ for $0.05 \mathrm{mmol} / \mathrm{L}$ in 1 -moolds), or $\mathrm{HOCl}$ ( $n=5$ loops for each concentration, except $n=$ 3 for $0.05 \mathrm{mmol} / \mathrm{L}$ in 1 -mo-olds). ${ }^{\text {s }} \mathrm{Cr}$-EDTA activity in plasma and in luminal perfusate was measured in a LKB CompuGamma spectrometer (model 1282, LKB Instruments, Inc., Gaithersburg, MD). At the completion of the experiment, the ileal loops were removed, rinsed with isotonic saline, patted dry, and weighed. The animals were killed with an i.v. injection of sodium pentobarbital.

Calculation of st Cr-EDTA clearance. The plasma-to-lumen clearance of EDTA was calculated as follows:

$$
\text { Clearance }=\frac{(\text { perfusate } \mathrm{cpm} / \mathrm{mL})(\text { perfusion rate })(100)}{(\text { plasma } \mathrm{cpm} / \mathrm{mL})(\text { wt of ileal segment in } \mathrm{g})}
$$

where clearance is expressed in $\mathrm{mL} \cdot \mathrm{min}^{-1} \cdot 100 \mathrm{~g}^{-1}$.

Data analysis. All values are expressed as mean \pm SEM. Clearance values were evaluated with age group and perfusate (for a given concentration) as the main effects by use of a repeated measures (over time) ANOVA. If the ANOVA revealed differences within or between age groups, the significance of individual data points was evaluated by use of Duncan multiple range tests (SAS Institute Inc., Cary, NC), Differences were considered significant at $p<0.05$.

\section{RESULTS}

Within age groups, perfusion of the ileal lumen with lactated Ringer solution for $240 \mathrm{~min}$ did not significantly alter ileal mucosal permeability measured using blood-to-lumen clearance of ${ }^{5} \mathrm{Cr}-\mathrm{EDTA}$ in either 1-d- or 1-mo-old piglets. Likewise, in ileal loops from l-mo-old piglets, mucosal permeability was not significantly increased over control with any concentration of $\mathrm{HOCl}$ or with $\mathrm{H}_{2} \mathrm{O}_{2}$ (except for a small, but significant increase with the highest concentration of $0.5 \mathrm{mM} \mathrm{H}_{2} \mathrm{O}_{2}$ ). In contrast, perfusion of the ileal lumen of 1 -d-old piglets with $0.1 \mathrm{mmol} / \mathrm{L}$ and $0.5 \mathrm{mmol} / \mathrm{L}$ concentrations of $\mathrm{H}_{2} \mathrm{O}_{2}$ and $\mathrm{HOCl}$ (Fig. $1 \mathrm{~A}$ and $B$ ) resulted in significant increases in ${ }^{51} \mathrm{Cr}$-EDTA clearances compared with control values. Although luminal perfusion with $0.05 \mathrm{mmol} / \mathrm{L} \mathrm{H}_{2} \mathrm{O}_{2}$ demonstrated a trend toward increased permeability in 1-d-old intestine (Fig. 1C), it did not reach statistical significance.

Evaluation of between-group differences showed that luminal perfusion with $0.5 \mathrm{mmol} / \mathrm{L} \mathrm{H}_{2} \mathrm{O}_{2}$ and $\mathrm{HOCl}$ (Fig. $1 A$ ) and 0.1 mmol $/ \mathrm{L} \mathrm{H}_{2} \mathrm{O}_{2}$ (Fig. $1 B$ ) led to significantly greater EDTA clearance in newborn intestine compared with that in 1-mo-old animals (for an equivalent concentration of perfusate). Perfusion
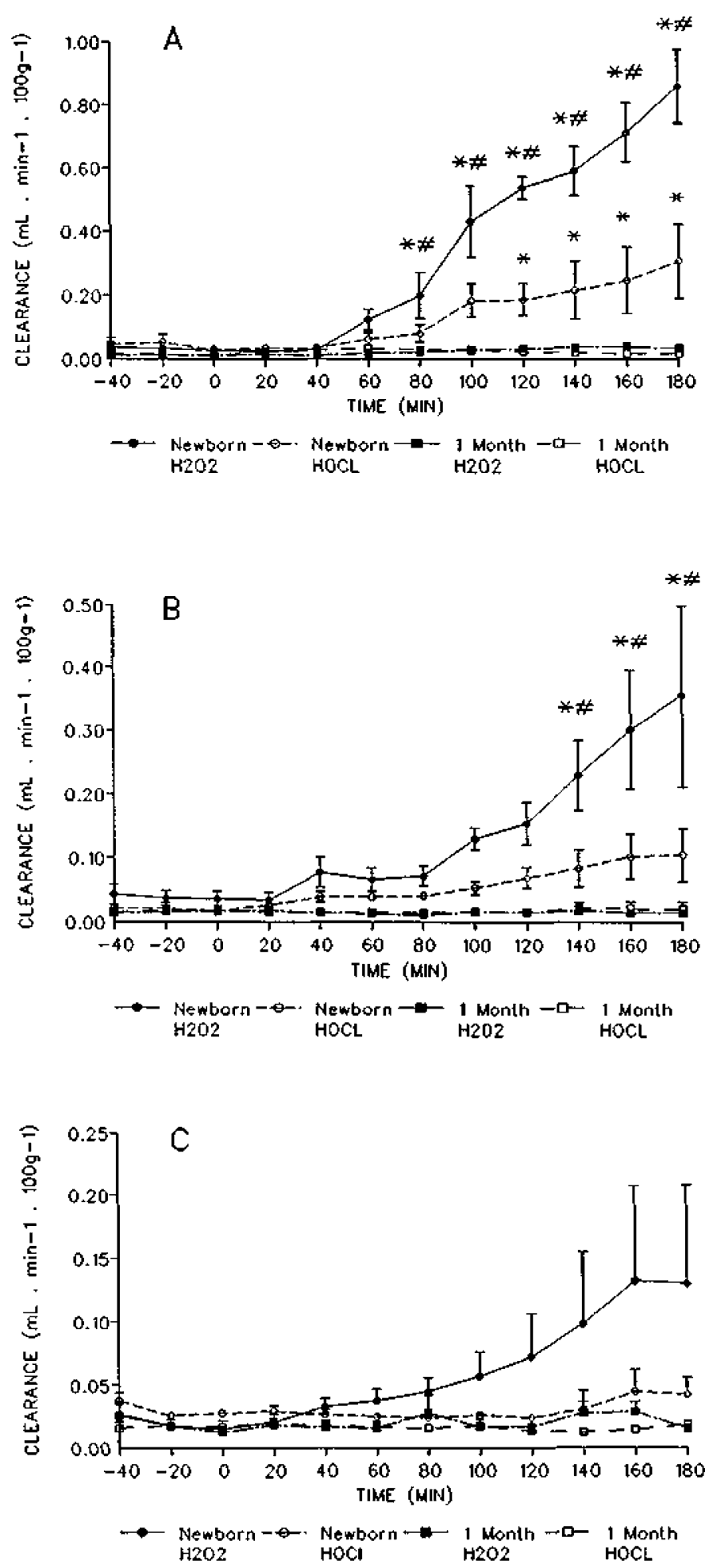

Fig. 1. "Cr-EDTA clearance during luminal perfusion with 0.5 $\mathrm{mmol} / \mathrm{L}(A), 0.1 \mathrm{mmol} / \mathrm{L}(B)$, and $0.05 \mathrm{mmol} / \mathrm{L}(C) \mathrm{H}_{2} \mathrm{O}_{2}$ and $\mathrm{HOCl}$ in piglet ileum. Control clearance during perfusion with lactated Ringers solution was measured for the first $60 \mathrm{~min}$, followed by $\mathrm{H}_{2} \mathrm{O}_{2}$ or $\mathrm{HOCl}$ perfusion beginning at time $=0$ min. ${ }^{*}$ indicates $p<0.05$ for 1 -d- $v s 1$ mo-old values and \# indicates $p<0.05$ for $\mathrm{H}_{2} \mathrm{O}_{2}$ vs $\mathrm{HOCl}$ perfusion.

with $0.1 \mathrm{mM} \mathrm{HOCl}$ caused no significant differences in mucosal permeability in 1-d- and 1-mo-old animals.

Comparison of equimolar concentrations of $\mathrm{H}_{2} \mathrm{O}_{2}$ and $\mathrm{HOCl}$ (Fig. $1 A, 0.5 \mathrm{mmol} / \mathrm{L}$ and $B, 0.1 \mathrm{mmol} / \mathrm{L}$ ) illustrates that luminal perfusion with $\mathrm{H}_{2} \mathrm{O}_{2}$ led to significantly greater injury to newborn intestine than did $\mathrm{HOCl}$. There was no significant difference in 